\title{
Triticum aestivum in open skin wounds: cytotoxicity and collagen histopathology
}

\section{Triticum aestivum em feridas cutâneas abertas: citotoxicidade e histopatologia de colágeno}

\author{
Mariana Teixeira Tillmann ${ }^{*}$; Cláudia Beatriz de Mello Mendes²; Geferson \\ Fischer ${ }^{3}$; Antonio Sergio Varela Júnior ${ }^{4}$; Cristina Gevehr Fernandes ${ }^{3}$; Márcia de \\ Oliveria Nobre ${ }^{3}$
}

\begin{abstract}
Phytoterapic compounds have been used in wound healing for many centuries. Nowadays, scientific evidences of phytotherapeutics is a requirement of the legislation. The scientific literature notes the need for healing topics yielding scars that are both aesthetically appealing and resistant. We aimed to evaluate the cytotoxicity of several doses of $T$. aestivum extract $\left(2 \mathrm{mg} \mathrm{mL}^{-1}, 4 \mathrm{mg} \mathrm{mL}^{-1}, 6 \mathrm{mg} \mathrm{mL}^{-1}, 8\right.$ $\mathrm{mg} \mathrm{mL}-1$ and $10 \mathrm{mg} \mathrm{mL}^{-1}$ ) in a fibroblast cell line and the healing process in an in vivo experimental model (New Zealand rabbits). For this, MTT test in 3T6 cells was performed in duplicates using MEM $\left(0 \mathrm{mg} \mathrm{ml}^{-1}\right)$ as negative control. Cell viability was calculated as: absorbance average in treatments/ absorbance average in controls x 100. In vivo test was performed in 78 skin wounds in rabbits that were treated with $2 \mathrm{mg} \mathrm{ml}^{-1}$ and $10 \mathrm{mg} \mathrm{ml}^{-1}$ of T. aestivum and non-ionic cream for 21 days. After this period, it was evaluated the histology using picrosorius and Gomori's trichrome staining. Statistical analysis was evaluated using $\mathrm{T}$ test (Graphpad) for cytotoxicity assay, Fischer test for the gomori trichrome test (Grahpad) and Kruskal-Wallis (Statistic 9.0) for picrosirius test. The in vitro test resulted in cytotoxicity observed at $2 \mathrm{mg} \mathrm{mL}^{-1}$ whereas cells were viable at higher doses. On the other hand, it was observed that collagen formation of wounds was more uniform with this dose than with $10 \mathrm{mg} \mathrm{mL}^{-1}$ extract in the in vivo study. Thus, we conclude that the $2 \mathrm{mg} \mathrm{mL}^{-1}$ T. aestivum aqueous extract dose was more efficient in the in vivo wound healing study, despite its cytotoxic effects in vitro.
\end{abstract}

Key words: Wound healing. Rabbits. Picrosirius. Gomori trichome. Wheat.

\section{Resumo}

Os extratos vegetais têm sido utilizados na cicatrização de feridas a muitos séculos. No entanto nos dias atuais a comprovação científica dos fitoterápicos é uma exigência da legislação. Na literatura científica se observa a necessidade de cicatrizantes tópicos que proporcionem uma cicatriz estética e resistente. Devido a isso objetivou-se avaliar a citotoxicidade de diversas doses de T. aestivum (2 $\mathrm{mg} \mathrm{mL} L^{1}, 4 \mathrm{mg} \mathrm{mL}^{-1}, 6 \mathrm{mg} \mathrm{mL}^{-1}, 8 \mathrm{mg} \mathrm{mL}^{-1}$ e $10 \mathrm{mg} \mathrm{mL}^{-1}$ ) em linhagem celular de fibroblasto, e o processo cicatricial em modelo experimental (New Zealand rabbits) in vivo. Para isso foi realizado o teste de MTT em linhagem celular 3T. Tests were performed in duplicates, using MEM $\left(0 \mathrm{mg} \mathrm{mL}^{-1}\right)$ as negative control. Cell viability was calculated as: absorbance average in treatments/absorbance average

1 Prof ${ }^{a}$ Dra , Universidade do Oeste de Santa Catarina, UNOESC, Xanxerê, SC, Brasil. E-mail: mariana.teixeira.tillmann@gmail.com Discente, Médica Veterinária, Universidade Federal de Pelotas, UFPel, Pelotas, RS, Brasil. E-mail: claudiabeatrizmm@gmail.com Profs. Drs., UFPel, Pelotas, RS, Brasil. E-mail: geferson.fischer@gmail.com; crisgevf@yahoo.com.br; marciaonobre@gmail.com

4 Prof. Dr., Universidade Federal do Rio Grande, FURG, Rio Grande, RS, Brasil. E-mail: varelajras@hotmail.com

* Author dor correspondence 
in controls x 100. No ensaio in vivo foram realizadas 78 feridas experimentais em coelhos que foram tratadas T. aestivum $2 \mathrm{mg} \mathrm{mL}^{-1}$, T. aestivum $10 \mathrm{mg} \mathrm{mL}^{-1} \mathrm{e}$ creme não iônico por 21 dias, após foi avaliado a histologia do tricrômico de golmori e de picrosirius. Na análise estatística do ensaio de citotoxicidade foi realizado o teste de $\mathrm{t}$ (Graphpad), para avaliação do tricomico de golmori foi realizado o teste de fischer (Graphpad) e no picrosirius foi avaliado através de Kruskal - Wallis (Statistic 9.0). O resultado in vitro demonstrou que a dose de $2 \mathrm{mg} \mathrm{mL}^{-1}$ foi citotóxica para as células e que doses maiores a essa apresentavam viabilidade celular. No entanto no estudo in vivo foi constatado que as feridas tratadas com essa dose apresentaram a formação de colágeno mais uniforme que as tratadas com $10 \mathrm{mg} \mathrm{mL}^{-1}$. Concluí-se que a dose de $2 \mathrm{mg} \mathrm{mL}^{-1}$ do extrato aquoso de T. aestivum é eficiente no ensaio in vivo com as feridas experimentais, o que não foi observado no estudo in vitro.

Palavras-chave: Cicatrização. Coelhos. Picro Sirius. Tricrômico de golmori. Trigo.

\section{Introduction}

Skin wound healing involves dynamic cellular and molecular processes leading to tissue regeneration (MCNES, 2006). Yet, it needs to occur gradually in order to generate a normotrophic and resistant tissue, allowing organized formation of conjunctive tissue and culminating in a maturation phase, with prevalence of type I and oriented collagenous fibres (WOLFRAM et al., 2009; KAHAN, et al., 2009; KIM et. al., 2013).

Moreover, the therapeutic action of phytotherapic compounds has been targeted in studies aiming at producing scars which are both aesthetically appealing and resistant (KRISHANAN, 2006; CESCA et al., 2012). Wheat (Triticum aestivum) features among plants with wound-healing properties for its anti-oxidant action and for the presence of fitostimolines which act over fibroblasts, stimulating the synthesis of collagen and glycosaminoglycans (MASTROIANNI et al., 1998; SOLÓRZANO et al., 2001).

In our previous study we found out that treatment with $2 \mathrm{mg} \mathrm{mL}^{-1}$ wheat extract was effective in yielding resistant scars. Yet, no diferences were observed between treatment and control during the histological analysis of wound healing with haematoxylin and eosin stain (TILLMANN et al., 2014). We thus propose this new study, where we evaluted collagen production as a justification for resistant scar formation.

Our goals were: to evaluate the cytotoxicity of T. aestivum extract doses $\left(2 \mathrm{mg} \mathrm{mL}^{-1}, 4 \mathrm{mg} \mathrm{mL}^{-1}\right.$,
$6 \mathrm{mg} \mathrm{mL}^{-1}, 8 \mathrm{mg} \mathrm{mL}^{-1}$ and $10 \mathrm{mg} \mathrm{mL}^{-1}$ ) in a fibroblast cell line; and to assess collagen type and formation during the healing of skin wounds upon treatment with $T$. aestivum doses for 21 days.

\section{Materials and Methods}

\section{Extract production}

The T. aestivum aquous extract used in this study (source: Herbarium PEL, $\mathrm{n}^{\text {o PEL 24.600) }}$ was obtained through ultrasound sonication. Fifty grams of wheat immersed in distilled water were subjected to sonication for 30 minutes at $30^{\circ} \mathrm{C}$. The main components of the extract were: carnosic acid (117 $\mathrm{mg} \mathrm{g}^{-1}$ ), kaempferol (163 $\left.\mathrm{mg} \mathrm{g}^{-1}\right)$, quercetin (77 mg $\left.\mathrm{g}^{-1}\right)$ e apigenin $\left(38 \mathrm{mg} \mathrm{g}^{-1}\right)$.

\section{In vitro toxicity assay}

The $3 \mathrm{~T} 6$ cell line, from the Universidade do Rio de Janeiro Cell Bank (BCRJ) was used. Cells were cultivated in Minimum Essential Medium (MEM) with $1 \%$ antibiotic solution and $8 \%$ fetal bovine serum (FBS). After formation of a confluent monolayer, aliquots were collected and sub-cultured in flat bottom 96-well plates where cytotoxicity was assayed after 48 hours using 3-(4,5-dimethylthiazol2-yl)-2,5-diphenyl tetrazolium bromide (MTT).

Extract doses used on the assay were the following: $2 \mathrm{mg}^{-1} \mathrm{~mL}, 4 \mathrm{mg} \mathrm{mL}^{-1}, 6 \mathrm{mg} \mathrm{mL}^{-1}, 8 \mathrm{mg}$ $\mathrm{mL}^{-1}$ e $10 \mathrm{mg} \mathrm{mL}^{-1}$ of $T$. aestivum aqueous extract in MEM. Tests were performed in duplicates, using 
MEM (0 $\left.\mathrm{mg} \mathrm{mL}^{-1}\right)$ as negative control. Cell viability was calculated as: absorbance average in treatments/ absorbance average in controls x 100, followed by t-test (Graphpad).

\section{In vivo assay}

The present study was approved by the animal experimentation ethics commission from the Universidade Federal de Pelotas (CEEA 510423110.005104\2009-13). Thirteen male New Zealand rabbits were used, weighting between $2-3 \mathrm{~kg}$ and kept in individual cages at Biotério Central (UFPel). Seventy-eight experimental wounds were produced via incisions made with punch $n^{\circ}$. 8. All the animals received dissociative anaesthetics (xylazine $5 \mathrm{mg} \mathrm{kg}^{-1}$ e ketamine $75 \mathrm{mg}$ $\mathrm{kg}^{-1}$ ) during the procedure, and were treated with analgesics (subcutaneous injections of tramadol chloride $2 \mathrm{mg} \mathrm{kg}^{-1}$, every 12h) for three days after the surgery (SCHANAIDER; SILVA, 2004).

Seventy-eight wounds were randomly divided in three groups, according to the treatments: wounds treated with cream containing $2 \mathrm{mg} \mathrm{mL}^{-1} T$. aestivum aqueous extract were called $\mathrm{T} 2$; the ones treated with cream containing $10 \mathrm{mg} \mathrm{mL} \mathrm{mL}^{-1} T$. aestivum aqueous extract were called $\mathrm{T} 10$ and the ones treated with non-ionic cream (control) were called TC. Following the treatments, dressings were made and exchanged every $24 \mathrm{~h}$ and the wounds were cleaned with $0.9 \%$ physiological saline solution. In addition, wound protection was made with hydrophilic and surgical gauze, which were also exchanged daily.

The three experimental groups were subdivided in groups according the day of euthanasia in seven, 14 and 21 days after the experiment, according to CFMV's, 2012. The areas containing the scars were dissected and placed in flasks with $10 \%$ formaldehyde, which were later sent to the Laboratório de Histologia - Instituto de Ciências
Biológicas, Universidade Federal de Rio Grande. Samples were processed in automatic tissue processor vacuum (Leica - ASP 200), imbedded and included in Paraplast Xtra (Sigma) and sectioned in an automated rotational microtome (Leica - RM2255), at standard width of $5 \mu \mathrm{m}$, with two consecutive cuts made per block. Slides were stained with Gomori trichome and Picrosirius stains.

\section{Histological analyses}

The presence or absence of collagen fibres were assessed on Gomori trichome slides, which were quantitatively analysed in optical microscope (bright field) (Olympus ${ }^{\circledR}$ São Paulo: Brazil), according Noronha et al., 2001. Picrusirius slides, on the other hand, were visualized under polarized light microscopy, and images obtained were analysed using the software Image $J^{\circledR}$, where collagen type and pixel percentage per area were assessed, according to Rich and Whittaker (2005) Statistical analysis of the in vitro assays were made using t-test (Graphpad). Gomori trichome stains were assessed using Fischer's test (Graphpad), and Picrosirius was evaluated using Kruskal- Wallis (Statistic 9.0).

\section{Results}

Results from the in vitro assay showed that only the $2 \mathrm{mg} \mathrm{mL}^{-1} T$. aestivum aqueous extract differed from the control and from the other treatments tested $(\mathrm{P} \leq 0.05)$, yielding less cellular viability (Figure 1).

Total collagen evaluation at the in vivo assay via Gomori trichome staining did not result in significant difference among the groups assessed each day ( $\mathrm{P} \geq 0.05$ ) (Figure 2). At day 7, T2 and TC groups displayed higher protein percentage than group T10 ( $80 \%, 60 \%$ and $40 \%$, respectively), while all groups displayed collagen on $100 \%$ of the wounds on the remaining time-points assessed (Figure 2 and 3). 
Figure 1. Cell viability percentage of $3 \mathrm{~T} 6$ cell line 48 hours after treatment with several doses of $T$. aestivum aqueous extract $\left(2 \mathrm{mg} \mathrm{ml}^{-1}, 4 \mathrm{mg} \mathrm{ml}^{-1}, 6 \mathrm{mg} \mathrm{ml}^{-1}, 8 \mathrm{mg} \mathrm{ml}^{-1}\right.$ and $\left.10 \mathrm{mg} \mathrm{ml}^{-1}\right)$. Different letters indicate statistical significance $(\mathrm{P} \leq 0.05)$.

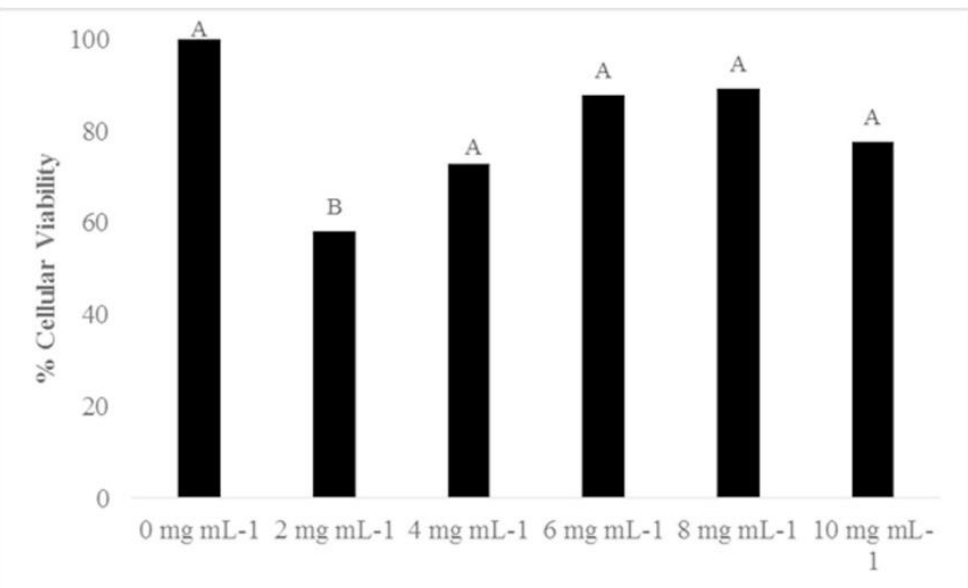

Figure 2. Figure demonstrated the evolution of collagen percentage in the different groups of open skin wounds from rabbits treated with $2 \mathrm{mg} \mathrm{ml}^{-1}$ T. aestivum aqueous extract (T2- A), $10 \mathrm{mg} \mathrm{ml}^{-1} T$. aestivum aqueous extract (T10- B) and non-ionic cream (CT- C) at 7, 14 and 21 day.

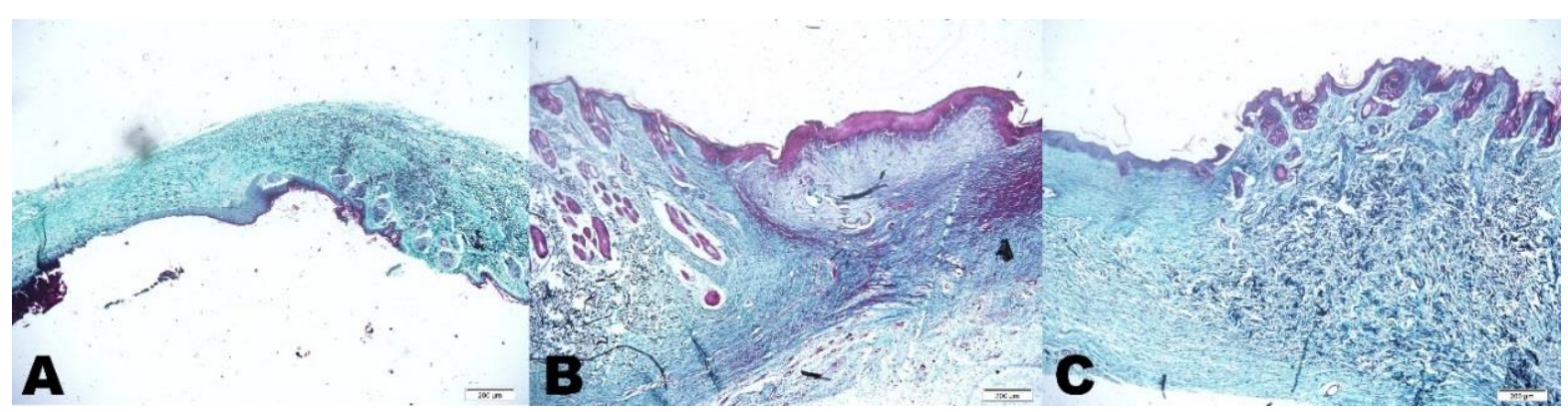

Figure 3. Graphic illustration of the collagen percentage on open skin wounds from rabbits treated with $2 \mathrm{mg} \mathrm{ml}^{-1} \mathrm{~T}$. aestivum aqueous extract (T2), $10 \mathrm{mg} \mathrm{ml}^{-1}$ T. aestivum aqueous extract (T10) and non-ionic cream (CT), at 7, 14 and 21 days. Different letters indicate statistical significance $(\mathrm{P} \leq 0.05)$.

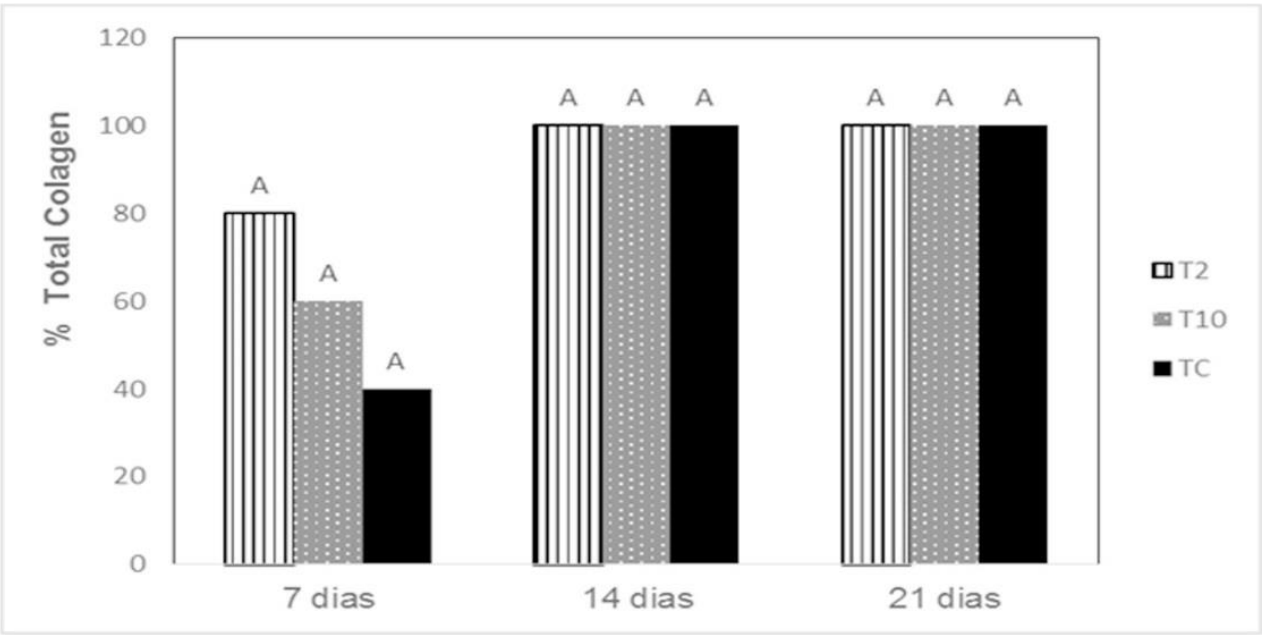


Assessment of collagen type through our observed that type I collagen formation was more experimental time-points showed constant formation of type I collagen on all groups tested. In spite of constant on groups T2 and TC than on T10 (Figure that, when collagen percentage was evaluated, we 4 and 5).

Figure 4. Photomicrography of collagen percentage on open skin wounds from rabbits treated with $2 \mathrm{mg} \mathrm{ml}^{-1} T$. aestivum aqueous extract (T2- A), $10 \mathrm{mg} \mathrm{ml}^{-1}$ T. aestivum aqueous extract (T10 B) and non-ionic cream (CT- C), at 7 days. Figure demonstrated that treated wounds with T2 and TC presented presence of collagen (blue coloration), while in the T10 treated wound do not have the protein.

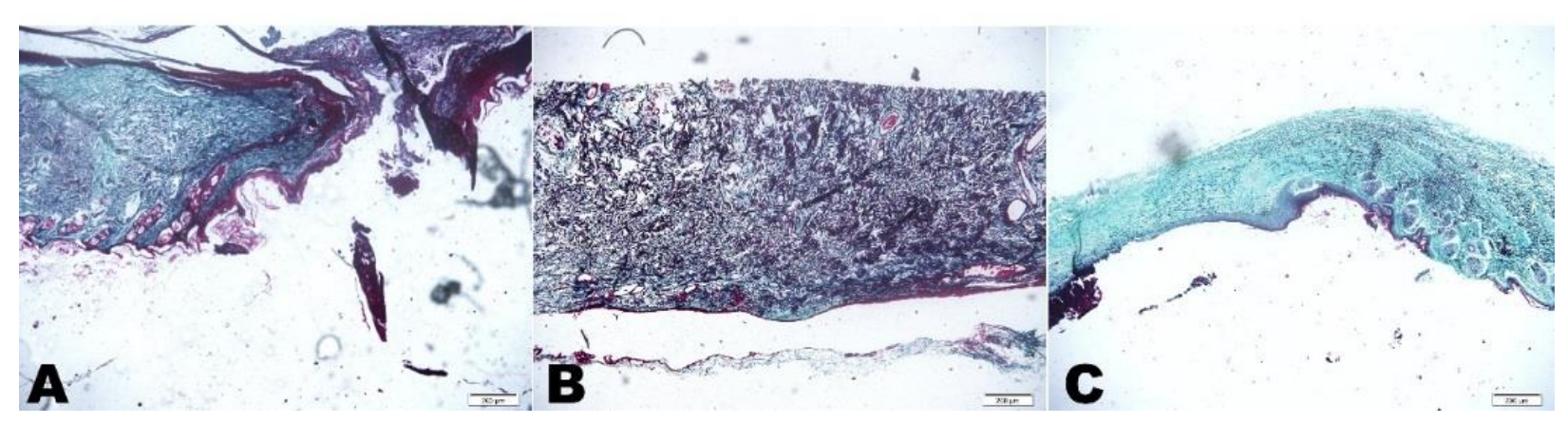

Figure 5. Birefringence percentage (picrosirius), at days 7, 14 and 21, of open skin wounds from rabbits treated with $2 \mathrm{mg} \mathrm{ml}^{-1}$ T. aestivum aqueous extract (T2), $10 \mathrm{mg} \mathrm{ml}^{-1}$ T. aestivum aqueous extract (T10) and non-ionic cream (CT). Different letters indicate statistical significance $(\mathrm{P} \leq 0.05)$.

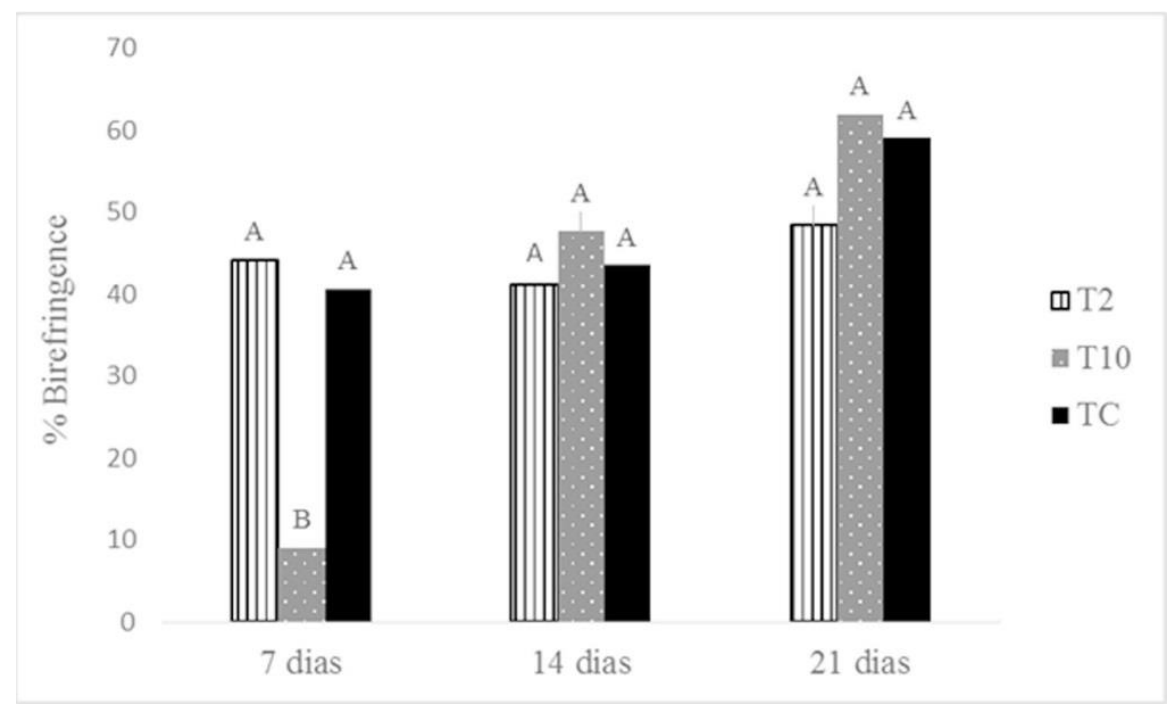




\section{Discussion}

It was observed in our results that wounds from group T2 and the control (TC) had similar responses at the histological analyses, being closer to the physiological scarring process (MANDELBAUM et al., 2003 BALBINO et al., 2005), which was not observed at T10 wounds. This fact justifies wounds displaying higher tension when treated with $2 \mathrm{mg}$ $\mathrm{ml}^{-1} T$. aestivum aqueous extract, as observed in previous studies (TILLMANN et al, 2014).

The reason for the treatment with the lowest $T$. aestivum concentration $\left(2 \mathrm{mg} \mathrm{mL}^{-1}\right)$ having yielded superior results than with the highest concentration is probably justified by the cytotoxic effect of the former over fibroblasts, as shown. While fibroblast are responsible for collagen synthesis, stimulating their production leads to heightened and faster tissue synthesis, preventing proper tissue alignment and maturation (KAHAN, et al., 2009; KIM et al., 2013). The dose being cytotoxic probably leads to cell death resulting in less and slower synthesis, thus allowing adequate tissue formation (SCHREML et al., 2010; SÜNTAR et al., 2012).

Moreover, the reason why the only cytotoxic dose on the cellular assay was $2 \mathrm{mg} \mathrm{mL}^{-1}$ is probably connected to the hormesis effect (LENZ et al., 2008), where lower doses lead to toxic effects similar to extremely high doses, which does not occur with average doses nor the control. In our experiment, the lowest $T$. aestivum extract dose tested $\left(2 \mathrm{mg} \mathrm{mL}^{-}\right.$ $\left.{ }^{1}\right)$ lead to damage in cell metabolism. Nonetheless, as the phytotherapic compound level was low, cells were unable to perceive the damage, thus causing a cytotoxic effect due to the absence of cell protection. On the other hand, average doses (of $4 \mathrm{mg} \mathrm{mL}^{-1}$, $6 \mathrm{mg} \mathrm{mL}^{-1}, 8 \mathrm{mg} \mathrm{mL}^{-1}$ ) prompted cells to respond to the metabolic damage caused by the compound, hence its deleterious effect was nulled out and cell toxicity was absent, as observed in the control group (CALABRESE; BRAIN, 2011).

It is possible that T. aestivum extract doses higher than $10 \mathrm{mg} \mathrm{mL}^{-1}$ lead to cytotoxicity as the $2 \mathrm{mg}$
$\mathrm{mL}^{-1}$ dose did, although in that case toxicity would be related to the inability of cells in containing damages caused by high extract dosages.

Type III collagen was not observed at wounds from the groups tested. Likely it was formed on the previous time-points, but at day 7 type I collagen was already being formed. During the total and type I collagen assessments it was observed that in wounds from groups T2 and TC, collagen formation occurred according to the physiological scarring process (MANDELBAUM et al., 2003; BALBINO et al., 2005), which was not observed in T10 wounds, since there was intense collagen formation between days 7 and 14. This sudden collagen formation likely prevented proper organization and maturation of the collagen fibres (KAHAN et al., 2009; KIM et al., 2013). As a consequence, the tissue formed in lesions from this group was less mature and displayed higher tension, fact that was not observed at wounds from the other groups tested (TILLMANN et al., 2014). In groups T2 and TC, on the other hand the protein was gradually formed, indicating the occurrence of proper cell signalling and flux to the lesion site, thus leading to formation of a tissue that was more mature tissue and had higher tensiometric strength (MANDELBAUM et al., 2003; BALBINO et al., 2005).

\section{Conclusion}

In this study we conclude that the $2 \mathrm{mg} \mathrm{mL}^{-1} T$. aestivum aqueous extract dose was more efficient in the in vivo wound healing study, despite its cytotoxic effects.

\section{Acknowledgements}

We would like to thank Capes and $\mathrm{CNPq}$ for providing a scholarship and funding for this project (CNPq 310619/2016-5). 


\section{Reference}

BALBINO, A; PEREIRA, M.; CURI, R. Mecanismos envolvidos na cicatrização: uma revisão. Brazilian Journal of Pharmaceutical Sciences, São Paulo, v. 41, n. 1, p. 27-51, 2005.

CALABRESE, E. J; BLAIN, R. B. The hormesis database: The occurrence of hormetic dose responses in the toxicological literature. Regulatory Toxicology and Pharmacology, Atlanta, v. 61, n. 1, p. 6173-6181, 2011.

CESCA, G.; FAQUETI, G.; ROCHA, W.; MEIRA, N.; MEYRE-SILVA, C.; SOUZA, M.; QUINTÃO, M.; SILVA, L.; CECHINEL FILHO, V.; BRESOLIN, B. Antinociceptive, anti-inflammatory wound healing features in animal models treated with a semisolid herbal medicine based on Aleurites moluccana L. Willd. Euforbiaceae standardized leaf extract: Semisolid Herbal. Journal of Ethnopharmacology, Atlanta, v. 143, n. 1, p. 235-5362, 2012.

CONSELHO FEDERAL DE MEDICINA VETERINÁRIA - CFMV. Guia brasileiro de boas práticas em eutanásia em animais - conceitos e procedimentos recomendados. Brasília: CFMV, 2012. p. 26-50.

KAHAN, V.; ANDERSEN, M. L.; TOMIMORI, J.; TUFIK, S. Stress, immunity and skin collagen: evidence from animal models and clinical conditions integrity. Brain, Behavior, and Immunity, Atlanta, v. 23, n. 8, p. 1089-1095, 2009.

KIM, J.; CARVALHO, C.; SOUZA, A.; GONÇALVES, C.; NOGUEIRA, V.; SPOLIDÓRIO, C.; ROQUEBARREIRA C.; CIRELLI, A. 2013. Topical application of the lectin Artin M accelerates wound healing in rat oral mucosa by enhancing TGF- $\beta$ and VEGF production. Wound Repair and Regeneration, Hoboken, v. 21, n. 3, p. 456-463, 2013.

KRISHANAN, P. The scientific study of herbal wound healing therapies: current state of play. Current Anaesthesia \& Critical Care, Atlanta, v.17, n. 1-2, p. 2127, 2006.

LENZ, M.; JANZEN, N.; LENS, P. N. L. Selenium oxyanion inhibition of hydrogenotrophic and acetoclastic methanogenesis. Chemosphere, Atlanta, v. 73, n. 3, p. 383-388, 2008.

MANDELBAUM, H.; DISANTIS, P.; MANDELBAUM, S. Cicatrização: conceitos atuais e recursos auxiliaresParte I. Anais Brasileiro de Dermatologia, Rio de Janeiro, v. 78, n. 4, p. 393-410, 2003.
MASTROIANNI, A.; CELlENO, L.; BORGIA, G.; CERIMELE, D. Léstratto acquoso di “'Triticum vulgare"valutazione clinico-istologica Nei processi riparativi tissutali cutanei. Giornale Italiano Dermatologia Venereologia, Torino, v. 133, n. 2, p. 145-53, 1998.

MCNES, P. Skin and wound assessment and care in oncology. Oncology Nursing, Atlanta, v. 22, n. 3, p. 130143, 2006.

NORONHA, L.; SCHULZ, R. T.; MARTINS, V. D. M.; AUERSVALD, A.; GRAF, R. Estudo comparativo das alterações histológicas imediatas causadas pelo uso do laser de $\mathrm{CO}_{2}$ e do larser erbium na pele de ratos wistar. Jornal Brasileiro de Patologia, Rio de Janeiro, v. 37, n. 4, p. 273-278, 2001.

RICH, L.; WHITTAKER, P. Collagen and picrosirius red staining: a polarized light assessment of fibrillar hue and spatial distribution. Brazilian Journal of Morphological Sciences, São Paulo, v. 22, n. 2, p. 97-104, 2005.

SCHANAIDER, A.; SILVA, P. C. Uso de animais em cirurgia experimental. Acta Cirúrgica Brasileira, São Paulo, v. 19, n. 4, p. 441-447, 2004.

SCHREML, S.; ROLF-MARKUS SZEIMIES, R.; LUKAS PRANTL, L.; LANDTHALER, M.; BABILAS, P. Wound healing in the $21 .{ }^{\text {st }}$ century. Journal of American Academy of Dermatology, Atlanta, v. 65, n. 5, p. 866881, 2010.

SOLÓRZANO, O. T.; HURTADO, H. R.; LÓPEZ, J. L. V.; PAQUENTÍN, J. Á.; GARIBAY, M. V. Evaluación de la actividad reepitelizante del Triticum vulgare en la cervicitis crônica erosiva. Revista de la Faculdade Medicina-UNAM, México, v. 44, n. 1, p. 79-83, 2001.

SÜNTAR, I.; AKKOL, E.; NAHAR, L.; SARKE, S. Wound healing and antioxidant properties: do they coexist in plants? Free Radicals and Antioxidants, Bangalore, v. 2, n. 2, p. 1-7, 2012.

TILLMANN, M.; FELIX, A.; MUELLER, E. N.; FELIX, S.; ALVES, G.; RAMOS, T.; FREITAG, R.; FERNANDES, C.; NOBRE, M. Use of Triticum aestivum in open wound healing: a clinical, pathological, and tensiometric assessment in the rabbit model. Arquivo Brasileiro de Medicina Veterinária e Zootecnia, Belo Horizonte, v. 66, n. 6, p.1757-1761, 2014.

WOLFRAM, D.; TZANKOV, A.; PÜLZL, P.; PIZAKATZER, H. Hypertrophic scars and keloids-a review of their pathophysiology, risk factors, and therapeutic management. Dermatologic Surgery, Hoboken, v. 35, n. 2, p. 171-181, 2009. 
